University of Wollongong

Research Online

Faculty of Law, Humanities and the Arts Papers (Archive)

Faculty of Arts, Social Sciences \& Humanities

$1-1-2019$

Buzz and Pipelines: Knowledge and Decision-Making in a Global Business Services Precinct

Simon Ville

University of Wollongong, sville@uow.edu.au

Claire Wright

University of Wollongong, clairew@uow.edu.au

Follow this and additional works at: https://ro.uow.edu.au/lhapapers

Part of the Arts and Humanities Commons, and the Law Commons

Research Online is the open access institutional repository for the University of Wollongong. For further information contact the UOW Library: research-pubs@uow.edu.au 


\title{
Buzz and Pipelines: Knowledge and Decision-Making in a Global Business Services Precinct
}

\author{
Abstract \\ This paper provides a historical analysis of an urban services district through its examination of the \\ Melbourne wool trade precinct in the 1920s. It is a study of both a local and global community whose \\ social and spatial interaction facilitated large-scale trade of a complex commodity that has rarely been \\ examined. Geographic mapping of the local and global connections of the precinct has been combined \\ with archival evidence. It reveals the "buzz" of the Melbourne precinct, created by local social and \\ professional connections among wool brokers and buyers. "Pipelines" to wool growing and textile regions \\ were developed through overseas branches of firms, with global knowledge exchanged through \\ correspondence, telegraph, and migration. These features shaped the progress of the trade, facilitating \\ improvements in its infrastructure and in the ability of Melbourne's wool brokers and buyers to fulfill their \\ role as intermediaries in the global supply chain for this complex commodity.

\section{Disciplines} \\ Arts and Humanities | Law

\section{Publication Details} \\ Ville, S. \& Wright, C. (2019). Buzz and Pipelines: Knowledge and Decision-Making in a Global Business \\ Services Precinct. Journal of Urban History, 45 (2), 191-210.
}


Buzz and pipelines: knowledge and decision-making in a global business services precinct

\section{Abstract}

This paper provides an historical analysis of an urban services district through its examination of the Melbourne wool trade precinct in the 1920s. It is a study of both a local and global community whose social and spatial interaction facilitated large scale trade of a complex commodity that has rarely been examined. Geographic mapping of the local and global connections of the precinct has been combined with archival evidence. It reveals the 'buzz' of the Melbourne precinct, created by local social and professional connections amongst wool brokers and buyers. 'Pipelines' to wool growing and textile regions were developed through overseas branches of firms, with global knowledge exchanged through correspondence, telegraph, and migration. These features shaped the progress of the trade, facilitating improvements in its infrastructure and in the ability of Melbourne's woolbrokers and buyers to fulfil their role as intermediaries in the global supply chain for this complex commodity. 


\section{Introduction}

A certain atmosphere filled the centre of the growing Australian coastal cities by the late nineteenth century. For Melbourne, as for most, it was the sight, sound and smell of wool on the move - vast volumes arriving from inland by road, river and rail, unloaded into warehouses, increasingly sold in auction rooms, and then loaded onboard vessels for shipment to overseas mills. Such fervent activity required manpower, horse power, equipment, and buildings that lined many city blocks. The rural sheep station was the source of wool production, but urban enterprise brought it to market and connected farmers to buyers across the world. The result, for bush and city, was prosperity that drove the Australian economy forwards beyond Federation.

The key to Melbourne's wool trade, though less discernible at first blush, was the quieter but constant 'throng' of wool firms, concentrated in a precinct along the western end of Collins Street and at the Melbourne Wool Exchange (MWE) around the corner in King St. A vast array of brokers, buyers and exporters conducted the buying and selling services of the trade. To extend the sound metaphor, there was a 'buzz' as leading firms and figures of the international wool trade mingled with one another in business, politics and social activities. In an era before scientific testing, the sale of an heterogeneous product like wool was infused with rich and diverse forms of proprietorial knowledge. Interaction enabled all parties to learn from one another about the numerous properties of wool and its complex sale process. Complementing the local buzz were national and international 'pipelines', which carried letters and cables updating firms and their representatives on the state of the market in Melbourne 
and around the world. ${ }^{1}$ The ability of sellers and buyers, at the service stage of the supply chain, to form accurate judgements from these multiple sources of information was critical to the success of production located on either side of the world - growing wool in the southern hemisphere and manufacturing textiles in the northern.

Our focus is Melbourne in the 1920s. Melbourne $(767,000)$ was the second most populous Australian city behind Sydney $(899,000)$ at the 1921 census and was at least three times the size of the next largest centres, Adelaide, Brisbane and Perth respectively. ${ }^{2}$ Along with Sydney, Melbourne had become one of the leading centres of the international wool trade after the relocation of the sales from Europe to the southern hemisphere from the late nineteenth century. It was also prominent in the Australian market, capturing 25 per cent of Australian wool sales. Brisbane, Adelaide, Fremantle, Albury, Geelong, Ballarat, Hobart, and Launceston were smaller selling centres in Australia. Wellington, Buenos Aires, Montevideo, and Cape Town were leading sales centres in the other major wool producing nations of New Zealand, Argentina, Uruguay and South Africa respectively. By the 1920s, market relocation was reaching its completion and many European woolbuying firms had set up branches in Australia. However, the trade faced many challenges, particularly the impact of World War One and the competition of artificial fibres.

By examining the role of urban services in the global supply chain of Australian resource exports, we contribute a commercial angle to what we already know about Melbourne as an industrial city. This provides a rare historical study of a service district rather than more commonly analysed industrial districts. We also contribute to studies 
of commodities and their global supply chains. Wool was a key element of the boom in primary produce selling that dominated world trade in the three decades before 1914, and yet is absent from recent studies of commodity chains. ${ }^{3}$ Our paper highlights the importance of multiple sources of knowledge for understanding the heterogenous character of wool, and the role of services in co-ordinating a highly-intermediated commodity trade. It utilises digital methods - in the form of geographic mapping - to understand the local and global connections of the wool precinct, complementing the emphasis of geography in the literature on business clusters. Finally, we illuminate a key issue in Australian economic history - the reasons for heavy urbanisation of the Australian population and the competing claims of town and country as the main source of development. ${ }^{4}$

In the remainder of the paper we analyse the operation of Melbourne's interwar wool precinct as a service cluster. Section II discusses the frameworks used to understand industrial districts and regional clusters, including the role of local and global connections in service industries. Section III explains the growth of local auction centres, and the role of wool in Australian development. Section IV describes the methodology used. Section V analyses the interactions of Melbourne-based firms in the local environment, and their connections to the global economy. Section VI examines how the buzz and pipelines of Melbourne's wool precinct shaped the progress of the trade in the 1920 s.

\section{Urban areas and industrial districts}


Industrial districts are areas of geographic, social, organisational, and institutional proximity, and are of interest to those seeking to foster innovation and develop regional economies. First specified by Alfred Marshall in the nineteenth century, ${ }^{5}$ the 'canonical Marshallian model' involves specialisation, information exchange, and pools of skilled labour arising from the concentration of small and medium enterprises from a particular sector in a local geographic area. ${ }^{6}$ Industrial districts fell from favour in the early twentieth century, in the wake of models of industrial progress that focussed on mass production by large, vertically-integrated corporations. Interest in industrial districts was revived in the 1970s by Italian scholars who observed a growing number of decentralised regions of firm agglomeration in the North of Italy. ${ }^{7}$ Since then, many analogous case studies have included districts in the UK and North America that produced light, labour-intensive goods like clothing and textiles, shoes, jewellery, and furniture. ${ }^{8}$

The 'canonical' model emphasises localised connections within a specific typology. In recognition of the contingent nature of economic and regional development, the model has been broadened to other agglomerations, including technological districts like Silicon Valley, media districts such as Los Angeles or Vancouver, and financial districts like the City of London..$^{9}$ Regional cluster has been adopted, most notably by Michael Porter, as a more inclusive definition that describes the ways in which concentrations of firms and institutions affect the development of a region. ${ }^{10}$

In regional clusters, physical agglomerations save on transport costs and create external economies of scale in the organisation and infrastructure of the trade. ${ }^{11}$ Pools of skilled 
labour ease recruitment, increase the chance that employees are members of 'invisible colleges' (and thus have interpersonal ties outside the organisation), and contribute to greater mobility between proximate firms. ${ }^{12}$ Clusters are also centres of interaction, increasing face to face encounters, reputation-building and accountability that encourages knowledge-sharing, trust, social capital and co-operation, and allows firms to monitor competitors. ${ }^{13}$ Clusters may have governance structures like trade associations, which curb opportunistic behaviours and provide services such as training, market forecasting, capital, and quality control mechanisms. ${ }^{14}$ Members may share socio-cultural traits - such as a similar social class or adherence to 'gentlemanly discourse' - that ease communication. ${ }^{15}$ They may benefit from access to the infrastructure of state or national capitals, large government institutions, or public universities. ${ }^{16}$ Agglomerations contribute to the flow of skills, knowledge, reputation, trust, and contacts. This achieves what Chandler argued was only possible through large vertically-integrated corporations - economies of scale, greater efficiency, and better co-ordination through the supply chain. ${ }^{17}$

While localisation is key for the operation of regional clusters, global reach is also vital for firms, serving as the 'pipelines' that channel resources amongst those in similar industries. Global connections are often facilitated through organisational links, as trade and communication across vast distances requires trust, accountability, and formal coordination. ${ }^{18}$ In the 'hub and spoke' form, one or several large firms play a pivotal role in local business by dominating the supply chain and engaging with global networks of inputs and investment. 'Satellite industrial platforms' involve large branch facilities, 
located in the district, but externally-owned and headquartered. ${ }^{19}$ Both models recognise the value of global communication for firms in a regional cluster, allowing them access to different knowledge than is available in the local area. This mitigates the stagnation of knowledge and labour market connections in the district. The local 'buzz' and the global 'pipelines' are thus complementary, with firms able to combine ideas from far-flung sources with those derived from proximate partners. ${ }^{20}$

The regional cluster has been an attractive framework with which to analyse the contextual and contingent nature of firm development over time. Most historical literature examines industrial production from the UK, including textiles in Yorkshire and Lancashire, jewellery-making in Birmingham, cutlery in Sheffield, and chemical manufacture in Widnes. ${ }^{21}$ Other locations - including East Asia, Continental Europe, America, and Australia - have been covered, if less frequently. ${ }^{22}$ There is a focus on the production of industrial goods, generally textiles or light manufactures, with little attention paid to the effects of agglomeration on other parts of the supply chain.

Similarly, Australia's urban economic history narrative has largely focussed on the rise and decline of manufacturing districts from about the 1860s to 1960s and their importance in shaping city development. ${ }^{23}$ Adopting a comparative perspective, though, McCarty and Frost have portrayed Melbourne as one of a series of new urban frontiers in the nineteenth-century settler economies alongside such cities as Auckland, Vancouver, San Francisco, Buenos Aires, and Los Angeles. ${ }^{24}$ In contrast to many earlier urban expansions, especially in Britain, Europe and the American east coast, these spacious cities consisted of both commercial and industrial districts, had a close 
relationship with resource extraction in the hinterland, and were surrounded by spreading surburbia in place of constricted inner slum areas. ${ }^{25}$

We study a service district - firms involved in brokerage, finance, and export services for the wool industry, clustered in a neighbourhood in downtown Melbourne. Services are generally viewed as subsidiary to traditional industrial districts - as benefitting from agglomeration but secondary to the main source of production. In the historical literature, service clusters are rarely examined, though Liverpool's trade networks, Majorca's tourism industry, and financial services in the City of London are exceptions. ${ }^{26}$ For Melbourne, the manufacturing expansion of the inner suburbs in the late nineteenth and early twentieth centuries was closely associated with local population growth and protective tariffs. We know less about the growth of export services in the central business district over a similar period except for the trading business of the leading mining firms largely conducted from a single building. ${ }^{27}$ Contrary to industrial districts, service clusters draw less on scale economies derived by large enterprises with sizeable labour forces and capital-intensive investments Although firm specialisation, pools of labour, and proximity to physical infrastructure are relevant, the key source of efficiency for service districts is as centres of knowledge and interaction. As the focus of service firms is on the provision of contacts and advice to clients, highquality, up-to-date knowledge is paramount to success. Clusters provide access to tacit knowledge through informal activities and face-to-face contact. They are the meeting place of the industry's press, and international pools of labour, increasing the district's access to global knowledge. ${ }^{28}$ Interactions with clients and co-operation with other 
firms are also key elements of service industries. Geographic proximity, particularly within urban areas, is necessary for building these types of relationships. Clusters are the meeting places where deals are made, relationships are established, and trust is generated. ${ }^{29}$

We contribute to the literature on regional clusters and industrial districts by analysing a distinctive service activity. We extend previous historical work on service districts by examining the clustering of services for the wool trade. Wool's specific features - as a tactile and heterogenous commodity - required up-to-date knowledge and highlytrained international traders. . This encouraged localisation around the main selling centres. Global connections played a complementary role, providing the pipelines through which the precinct had access to knowledge and contacts at either end of the supply chain. The wool trade is thus an excellent example of complementarity between local 'buzz' and global 'pipelines' in regional clusters.

\section{Formation and growth of the Australian wool market}

Wool production and export featured large in the colonial Australian economies from the $1820 \mathrm{~s}^{30}$ The reproducible nature of livestock, the rapidly rising demand for wool by British then European textile manufacturers, and the availability of foreign finance drove the continual expansion of settlement across much of Australia and the growth in the size of the clip through the nineteenth century. 'Squatters', who settled on land without legal title, exploited the comparative advantage in pastoralism: low labour costs 
and cheap inland grazing in lower rainfall areas. Land legislation by mid-century provided some security for squatters while also making provision for smaller scale more intensive pastoralism and farming. Except during the mining boom of the $1850 \mathrm{~s}$ and the severe drought from the mid-1890s, wool dominated exports with a share averaging 40 to 50 per cent in the 1870 s and 1880 s, reaching 56 per cent in $1891 .{ }^{31}$ This helped to fund the importation of capital equipment and manufactures. Australia became the world's largest wool producer and exporter by the end of the nineteenth century accounting for around 40 per cent of global exports. ${ }^{32}$ From the 1890 s, refrigerated exports of meat provided alternative choices for graziers between finewool producing merino or crossbreed sheep, the latter yielding lower quality wool but a more valuable carcass.

Wool faced challenges as a source of progress. Critics have observed the lack of modern technology or linkages to other parts of the economy that might have sustained this initial growth through diversification. ${ }^{33}$ Like most commodities, demand and supply were cyclical. The mining booms of the 1850s threatened to denude the pastoral sector of labour and finance. This was short-lived but the financial crisis of the early 1890s, followed by the drought years 1896-1902, depressed profits and halved the sheep population. Guaranteed sales at high prices to the British government's monopsony in World War One brought a return to prosperity. The 1920s were difficult years with a postwar production glut, lower prices, debates over future marketing methods, and the rise of alternative fibres. Nonetheless, and despite an advancing manufacturing sector, 
wool continued to dominate the nation's exports in this decade, with a share of around 30 per cent. ${ }^{34}$

When Australian wool exports came to prominence in the mid nineteenth century, most wool was consigned to London, where it was sold by auction and the proceeds returned to Australia through trading banks. ${ }^{35}$ For various reasons, particularly the growing geographic diversification of buyers to include Japanese and many Continental European firms, the wool auctions shifted from London to the Australian port cities from where purchases were shipped directly to the buying nation. ${ }^{36}$ This process began in the last two decades of the nineteenth century and was largely complete by the 1920s. A similar shift to domestic sale occurred in the other major wool growing nations of New Zealand, South Africa, Argentina and Uruguay.

As the wool market shifted to Australia some of the local stock and station agents who had forwarded farmers' wool to London reinvented themselves as wool brokers to conduct the Australian auctions. Regional wool broking associations came into being from the 1890s to coordinate auctions in each city among these firms. After World War One, a national body, the National Council of Wool Selling Brokers in Australia (NCWSBA), was formed to coordinate sales nationally at a time of oversupply. Foreign wool buyers, who had pushed for local sales to avoid an entrepôt trade via London, established overseas branches in Australia. For growers, it meant the opportunity to observe the sale of their wool at auctions. From being little more than a minor node on the global supply chain, the Australian cities became the centre of the critical decisionmaking services of the trade. Sydney and Melbourne became the largest wool markets 
in the world, outcompeting the long-established markets of London and Continental Europe.

Australia's sheep population was predominantly merino with a minority of cross-breed types. There were numerous specific breeds pastured across widely differing climatic regions and under different farming practices, which affected the qualities of the wool produced. ${ }^{37}$ The land subdivision policies of the second half of the nineteenth century, the opportunities for mixed farming brought about by refrigeration, together with returning soldier settler schemes after World War One created many different groups of wool producers. As Belgian woolbuyers Dewez noted, 'The buying of wool and sheepskins is an intricate business which demands expert knowledge and infinite care'. 38

The heterogeneous character of wool required a different form of marketing from other commodities that were sold directly to merchants or processors. Selling brokers, acting as intermediaries between the growers and buyers, provided comprehensive marketing services in return for a percentage commission. They needed immense knowledge of the complex wool trade in order to get the best deal for their farmer clients. Woolbuyers equally needed to form judgements about the suitability of each wool lot for the manufacturing needs of their overseas principals. Among the various criteria they looked for were the length, diameter, crimp and hue of the fibre. By the 1920s there were around 1500 different micron cross-sectional measures of fineness. Most wool was sold and exported in its greasy raw form and therefore the buyer had to estimate its likely yield after cleaning and scouring. For both broker and buyer some of these 
qualities were measurable, others relied on experiential knowledge that necessitated viewing and handling the wool. Finally, growers needed to understand how their wool was sold and the choices made by buyers to feedback into their business decisions. The wool service district facilitated a closely-knit trading community of small, human capital rich firms from across the globe for whom diverse but accurate commercial and product information and tactile skills were critical features.

\section{Visualising Melbourne's wool precinct}

To understand Melbourne's interwar wool precinct, we have combined digital and archival historical methods. We have mapped the local and global connections of wool brokers using geographic information systems (GIS) software. The use of geographic mapping for historical inquiry is well-established. ${ }^{39}$ Software such as QGIS combines attribute and spatial data, visualising the nature of various phenomena in relation to their location on a world map. ${ }^{40}$ Despite the importance of geography for industrial districts, the historical literature has rarely used digital methods to map firms based on their geographic location. ${ }^{41}$ Our data are based on Skinner's The world's wool (hereafter referred to as 'Skinner's'), an annual directory of the trade that commenced in 1927. This lists every firm worldwide that was involved in the buying and selling of wool, including their locations within each country, and the functional activities that they engaged in. The names, locations, and functions of firms listed in the directory have been transcribed into a vast dataset that indicates the global reach and geographic 
agglomeration of the international wool trade. The Skinner's directory has been supplemented by other sources, primary and secondary, to derive as accurate a demographic record of the precinct as possible.

The names and addresses of all firms in Melbourne in 1927 were matched with longitude and latitude co-ordinates. Working with QGIS, the result is a map of the Melbourne CBD, with point markers showing the location of firms, and larger point markers indicating that more than one firm held an office at that address. The data were contextualised by overlaying an historic map of Melbourne from the 1927 Morgan's Street Directory. ${ }^{42}$ The Skinner's database was then used to map national and global connections for our population by matching the list of Melbourne-based firms with their other offices interstate or overseas. The locations that each firm operated in were recorded and matched with longitude and latitude co-ordinates for that city. In QGIS, this resulted in a global map, with ties between Melbourne and other cities based on whether a firm had operations in both. Visualising these data with ties (rather than simply point markers) emphasises that the Melbourne wool precinct was connected to a global system of trade, migration, capital, and information.

Building on this geographic visualisation is an analysis of the way in which this precinct operated. The database evidence of firm functions illuminates specialisation and complementarity between wool trade firms, and differences between local firms and those oriented nationally or internationally. Archival records for the major wool trade bodies in Melbourne in the 1920s complements this evidence. These include the wool buyers and brokers associations, the MWE, and the local meetings of the NCWSBA. The 
papers of Belgian woolbuyer, Toussaint Dewez, indicate a firm embedded in the precinct but with extensive overseas branches and global trade routes. ${ }^{43}$ The archives demonstrate the interactions among firms and individuals within the wool precinct and connecting to their overseas offices, particularly through regular meetings supported by statistics and correspondence.

\section{Local buzz and global pipelines}

Melbourne's location on the Yarra River, at the head of Port Phillip Bay, and close to the ports of Williamstown and Port Melbourne provided an ideal location for interstate and international trade. Its CBD developed from a rectangular grid, originally designed by Robert Hoddle, about a mile long and half a mile wide. Flanked by industrial inner city surburbs, such as Fitzroy and Collingwood, by the later nineteenth century, the CBD became a thriving business services centre with proximity to government buildings, and suburban and intercity train services. ${ }^{44}$

By 1927, 121 wool trade firms operated from Melbourne's CBD; only Sydney hosted more firms. Figure 1 applies street addresses of firms listed in Skinner's to a contemporary street map of the CBD grid to reveal the location and density of the wool trade. All but one of the firms were located within what we describe as the 'wool precinct', an area covering a rectangular block of six streets by three and proximate to the rail and port connections at the west end of the CBD. The original location of wool trade firms, prior to the auction system, was determined by its proximity to a freight 
transport hub consisting of Spencer St railway station, the lower Yarra riverdocks and wharfside warehouses. ${ }^{45}$ However, following the relocation of the auction system, this area transformed from a freight trans-shipment place to a thriving business services precinct. ${ }^{46}$ Distances within the precinct were easily walked within a few minutes and the limited road traffic fostered a high degree of intimacy and connection among premises. ${ }^{47}$ Most firms were concentrated in Collins, Little Collins St (45 firms), King St (37), and William St (25) with a remaining handful in Flinders, Bourke or La Trobe Streets.

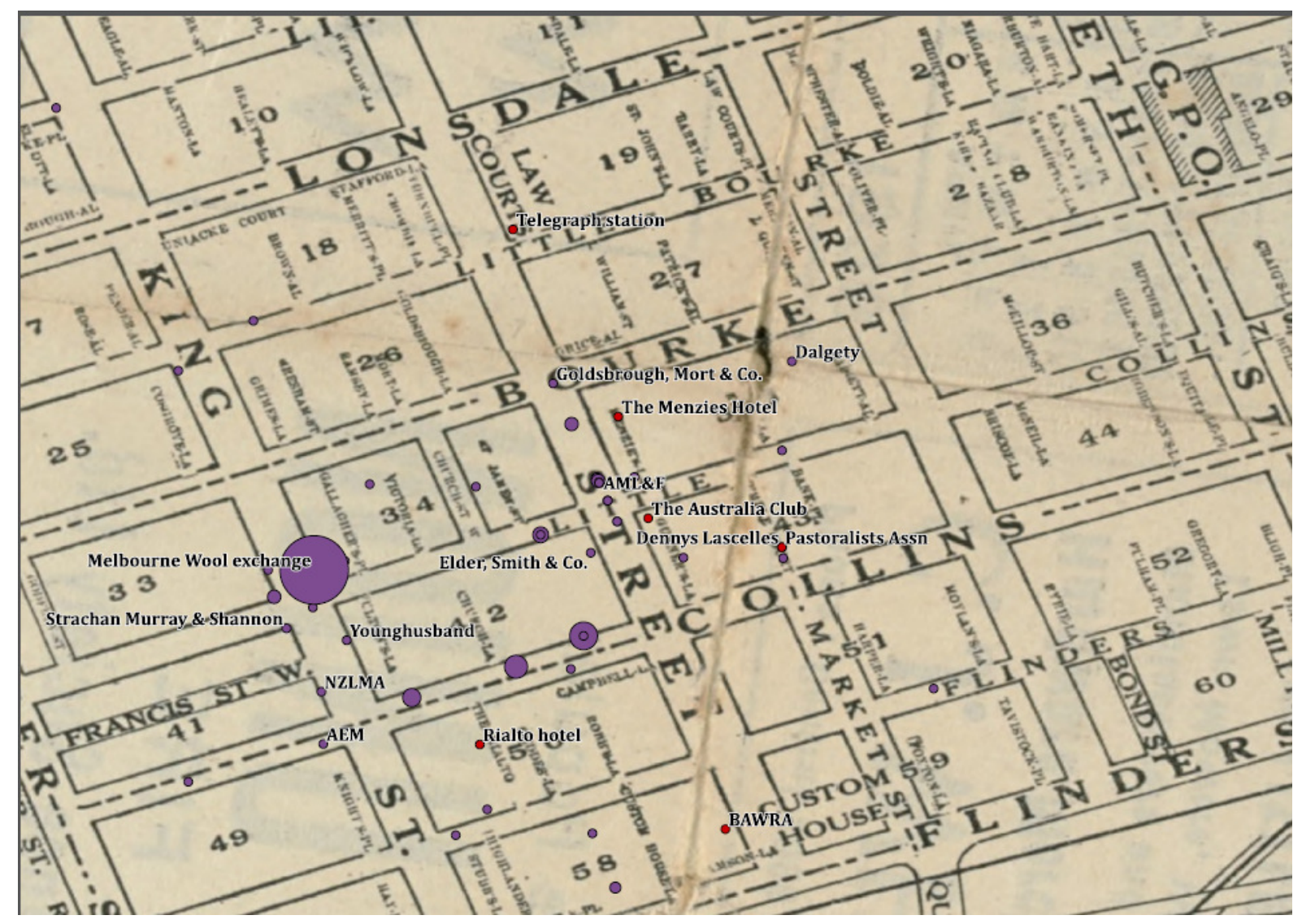

Figure 1. Melbourne's wool precinct. Data based on listings in Skinner's The world's wool. Point markers indicate a firm had their office at that address. Larger point markers indicate that more firms had their offices at that address. Scale 1:2,946. 
The largest concentration was 28 firms that rented offices at $122 \mathrm{King}$ St, the home of the MWE. The Exchange was built in 1911 with the intention of becoming the 'pastoral centre of Melbourne'.48 It was a striking four-storey building whose central feature was an impressive purpose-built amphitheatre saleroom that was surrounded by a series of offices. ${ }^{49}$ While its primary function was to conduct regular wool auctions, it served as a central institution and a key meeting point within the precinct. Brokers and buyers met here almost daily for the conduct of the auctions. Industry associations rented offices and held regular meetings in the building. Jointly owned by the largest broker firms through their industry body (the Melbourne Woolbrokers Association, hereafter the MWA), the Exchange's other tenants indicate its wider relevance to local trade, politics and society - the Pastoral Review, the West End Club, the Parliamentary Works Committee, Valentine Publishing, and the War Museum (see figure 2). In addition, lectures that provided education and information about the wool trade were organised in the saleroom..$^{50}$ Association with key infrastructure of the wool trade developed legitimacy and reputation amongst trading firms, industry associations, and subsidiary organisations. 


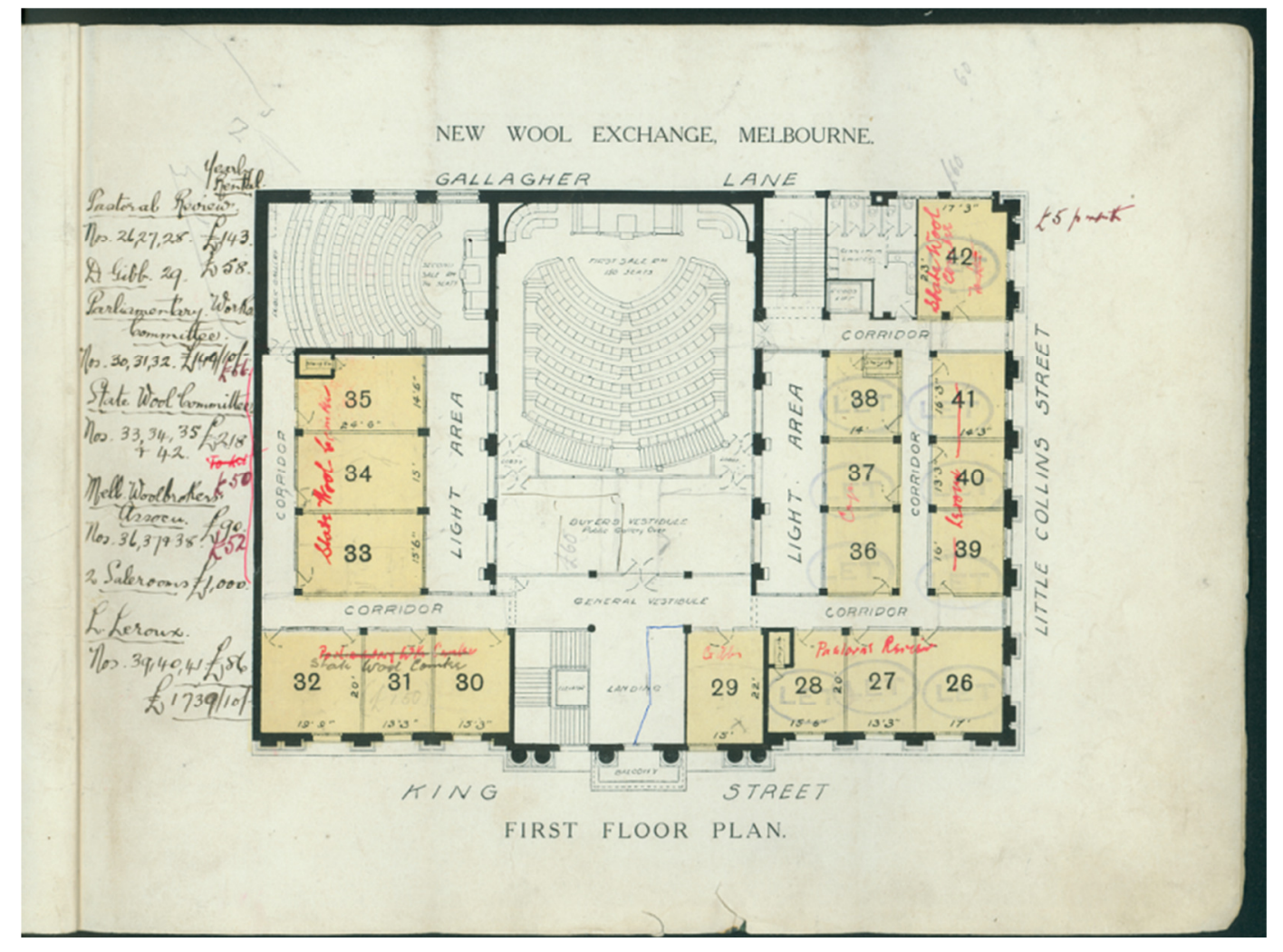

Figure 2. Melbourne Wool Exchange, first floor plan. Source: UMA 2006.0121, box 2, Victorian Woolbrokers Association.

Further concentrations of firms existed around the junctions of William with Collins and Little Collins streets. The Australia Club was embedded in this neighbourhood, providing an opportunity for conversations and social interaction beyond business premises, but with a view to building knowledge and connections within the trade. ${ }^{51} \mathrm{~A}$ block further north on William St the Menzies Hotel was used for social interaction and business meetings. The wool precinct was a place where friendships were made, trust built, and knowledge exchanged. 
However, the connections of the Melbourne wool trade extended far beyond its western CBD precinct. Hastened by the nineteenth-century revolution in transport and communications, commodities, people, finance and information were carried great distances across the Australian continent and much of the globe. The rail system reached into the pastoral districts and connected colonies and cities by the end of the nineteenth century. Combined with the coastal trade, it carried buyers interstate between sales, wool from the hinterland, and brokers to maintain contact with their network of inland branches and agencies. At least 41 firms had branches in other parts of Australia, especially buyers in Sydney and brokers in the hinterland. The advent of oceanic liner trades in the second half of the nineteenth century and the introduction of steam to the long intercontinental voyages by the early twentieth, facilitated the distribution of wool exports to distant parts of the globe. Accompanying it was a correspondence written by buyers and brokers containing rich descriptions of wool markets, reinforced by visits back to head offices in the auction close season for personal briefings.

Transport routes were complemented by telegraphic communication, which provided instant market information and the exchange of views across the globe. The first telegraph office in the southern hemisphere had been established in the Melbourne wool precinct in 1854 at the north-east corner of William and Little Bourke streets. Initially, this connected locally to the port of Williamstown for prompt information about shipping arrivals, but by 1872 the oceanic cable connected to Europe providing timely market information for buyers in Melbourne. By the 1920s weekly market 
reports were transmitted from Australia to national wool industry organisations throughout the northern hemisphere, particularly the British Wool Federation, Union des Negociants en Laine (France), the American Wool Association, and Japan Wool Importers Association who shared this information with local manufacturers. Buyers entries in Skinner's provide details of the telegraph companies who handled their own commercial-in-confidence messages, often encrypted, while they also drew on popular code books, such as ABC or Bentley's, that were designed to save money by reducing common phrases to single words. ${ }^{52}$ Woolbuyers Dewez relied upon individual codes for their extensive list of clients worldwide, and private codes for market-sensitive information. ${ }^{53}$

Table 1: Office locations of Melbourne firms

\begin{tabular}{|r|c|}
\hline \multicolumn{1}{|c|}{ City } & Number of firms \\
\hline Sydney (AU) & 38 \\
\hline Roubaix-Tourcoing (FR) & 17 \\
\hline London (UK) & 12 \\
\hline Brisbane (AU) & 11 \\
\hline Fremantle (AU) & 10 \\
\hline Wellington (NZ) & 9 \\
\hline Bradford (UK) & 8 \\
\hline Port Elizabeth (ZA) & 8 \\
\hline Adelaide (AU) & 7 \\
\hline Buenos Aires (AG) & 9 \\
\hline Christchurch (NZ) & 6 \\
\hline Perth (AU) & 5 \\
\hline East London (ZA) & 4 \\
\hline Durban (ZA) & 3 \\
\hline Montevideo (UR) & 3 \\
\hline Auckland (NZ) & 2 \\
\hline Bahia Blanca (AG) & 2 \\
\hline Dunedin (NZ) & 2 \\
\hline Geelong (AU) & 2 \\
\hline
\end{tabular}




\begin{tabular}{|r|r|}
\hline Toronto (CA) & 2 \\
\hline Antwerp (BG) & 1 \\
\hline Basel (SW) & 1 \\
\hline Galashiels (SC) & 1 \\
\hline Huddersfield (UK) & 1 \\
\hline Launceston (AU) & 1 \\
\hline Leicester (UK) & 1 \\
\hline Leipzig (GM) & 1 \\
\hline Liverpool (UK) & 1 \\
\hline Mazamet (FR) & 1 \\
\hline Palmerston North (NZ) & 1 \\
\hline Rouen (FR) & 1 \\
\hline Tianjin (CH) & 1 \\
\hline Tokyo (JP) & 1 \\
\hline Verviers (BG) & 1 \\
\hline
\end{tabular}

Note: Firm locations based on listings in Skinner's The world's wool. Many firms had offices in more than one location, so the total number of cities is greater than the total number of firms.

Table 1 lists 42 firms in the Melbourne wool trade with overseas offices in 1927. As firm advertisements in Skinner's intimate, many also had overseas agencies. Thomas Laycock, a Bradford wool merchant, had branches in Melbourne, Sydney, Christchurch and Port Elizabeth as well as agencies in Boston, Colmar, Bremen, Amsterdam, and Gothenberg. Based on the data in table 1, figure 3 uses QGIS to show connections between Melbourne and other cities where a firm had branch operations in both locations. Thicker ties indicate a greater number of firms traded in both cities. Figures 4 and 5 show the Australasian and European regions in more detail. Melbourne firms had offices in fourteen countries across six continents. Melbourne was thus part of a global trading system - with very strong connections across Australia, to the UK and Western Europe. The connections to the other southern hemisphere growing centres, in New 
Zealand, South Africa, Argentina and Uruguay, indicated buyers arbitraging between the different national markets. Firms had to possess a close understanding and knowledge of the wool qualities offered for sale in each market and timely information about changes in supply and prices across centres.

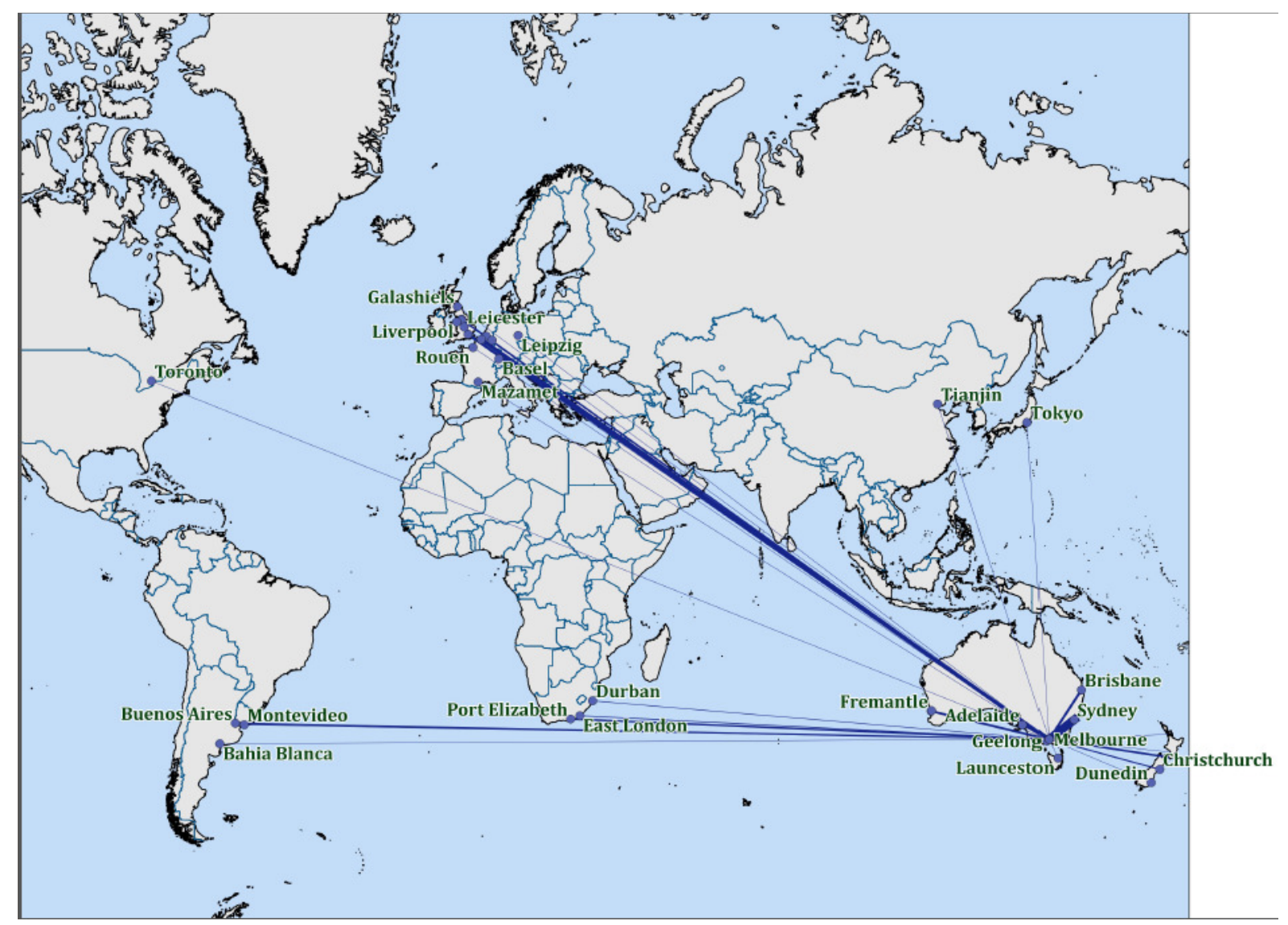

Figure 3. Global wool connections from Melbourne. Data based on listings in Skinner's The world's wool. Ties between Melbourne and other cities indicate that a firm had offices in both cities. Thicker ties indicate that a greater number of firms had offices in both cities. Scale 1:105,000,000. 


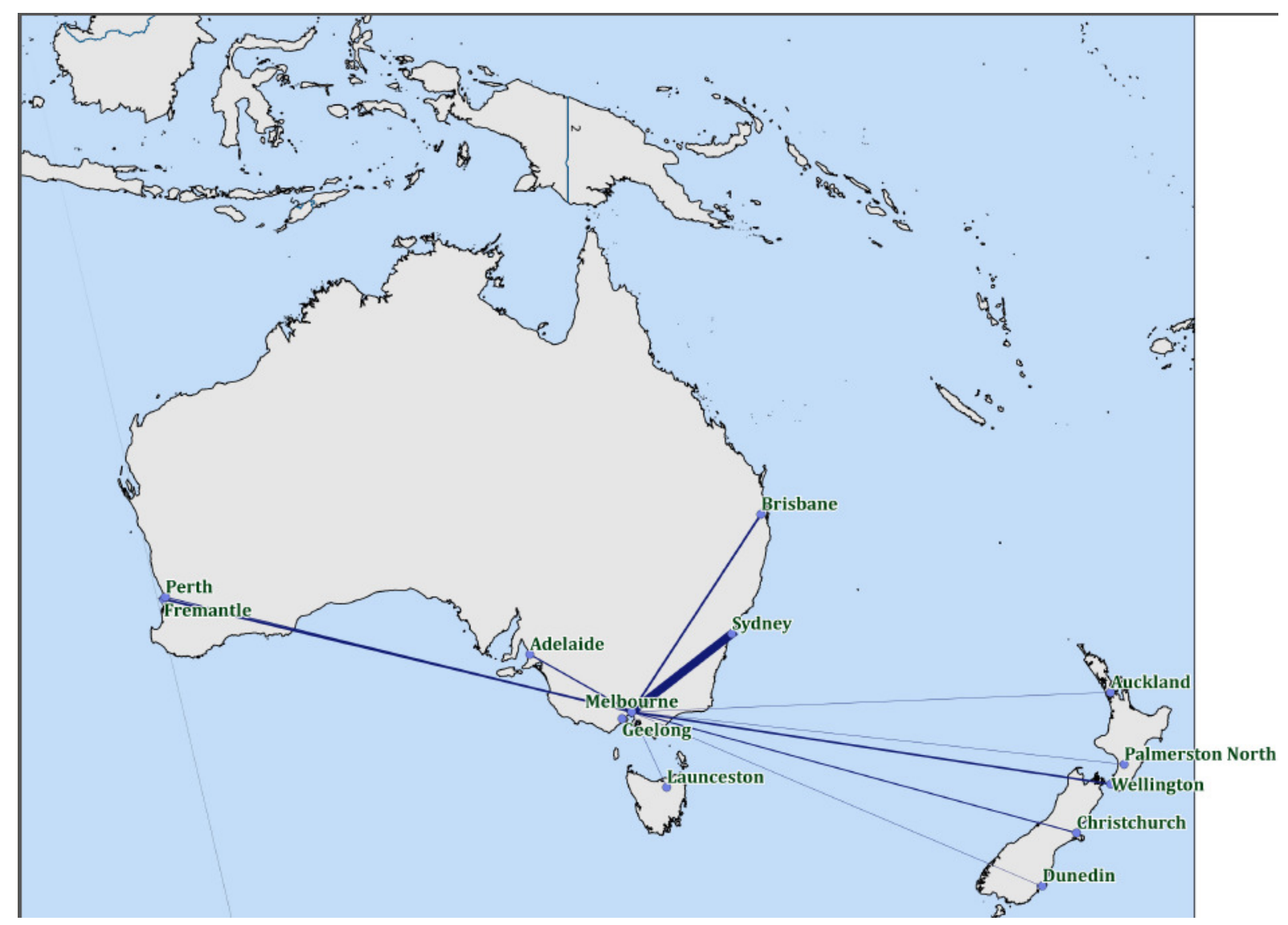

Figure 4. Australasian wool trade networks. Data based on listings in Skinner's The world's wool. Ties between Melbourne and other cities indicates that a firm had offices in both cities. Thicker ties indicate that a greater number of firms had offices in both cities. Scale 1:31,000,000. 


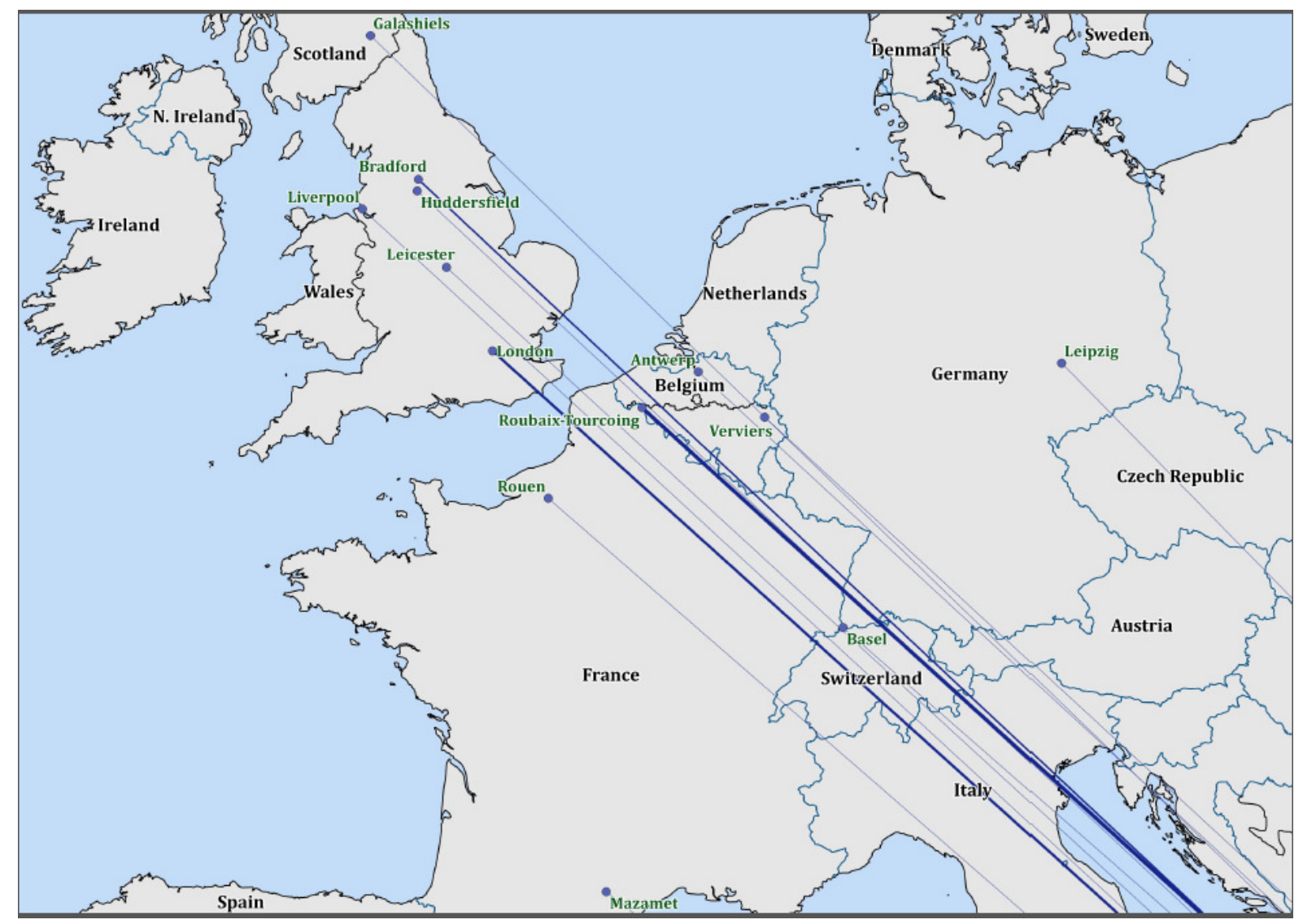

Figure 5. Wool connections to Northern European textile centers. Data based on listings in Skinner's The world's wool. Ties between Melbourne and other cities indicates that a firm had offices in both cities. Thicker ties indicate that a greater number of firms had offices in both cities. Scale 1:15,500,000.

Connections to the northern hemisphere were to supply the woollen textile industries of Europe, particularly Bradford in the UK and the Lille-Tourcoing-Roubaix district in the borderlands of France and Belgium, commonly known as Flanders. These were two of the principal woollen manufacturing areas in Europe. ${ }^{54}$ There were more modest connections into North America, who predominantly drew on domestic supply sources behind a wool tariff. ${ }^{55}$ Asian branches in Japan and China were very few but grew 
substantially later in the twentieth century. ${ }^{56}$ The only Asian connection in 1927 was Mitsui's from Melbourne and Sydney to Tientsin (Tianjin) and its head office in Tokyo. Japanese imports of Australian wool grew rapidly in the interwar period but the absence of greater connections may reflect the size, diversity and vertical integration of Japanese firms, mostly zaibatsu, compared with the European buyers. Their focus was their corporate pipeline back to Tokyo more than the buzz of Melbourne. Mitsui along with Kanematsu, who were the first Japanese buyers in Australia established in Sydney in 1890, accounted for 50 per cent of Japanese wool imports from Australia in 1931-2. They transported this wool, along with wheat, metal and ores, in company ships for use in their own factories in Japan. ${ }^{57}$

As we noted earlier, the wool trade consisted of several distinct groups of firms primarily wool selling brokers and wool buying firms. Wool was purchased through buying brokers on behalf of their customers or bought directly by buyers representing manufacturers. Table 2 indicates the distribution of firms between these functions.

Table 2: Wool trade firms of Melbourne by function

\begin{tabular}{|r|c|}
\hline \multicolumn{1}{|c|}{ Function } & Number of firms \\
\hline Wool broker (buying and selling) & 67 \\
\hline Merchant & 55 \\
\hline Wool buying broker & 31 \\
\hline Buyer & 19 \\
\hline Exporter & 10 \\
\hline Wool selling broker & 6 \\
\hline Agent & 1 \\
\hline Auctioneer & 1 \\
\hline
\end{tabular}


Note: Functions based on listings in Skinner's The world's wool. Many firms listed more than one function, so the total number of functions is greater than the total number of firms.

About nine selling brokers conducted the auctions. A couple were local Victorian firms, the others sold across most of the Australian city auctions. Two brokers also operated in New Zealand, and four had an office in London, which was partly a legacy from the older tradition of London sales but also enabled them to keep abreast of developments in the London auctions that continued on a smaller scale. Their main attention, though, was their farmer clientele spread far and wide across Victoria and interstate. As we saw earlier, many brokers had their origins as rural stock and station agents and continued to draw heavily upon networks of branches or local agencies in pastoral areas for their supply of wool to sell but also for their sources of knowledge about its production. While ostensibly competitors, the selling brokers developed strong co-operative practices to ensure the auction functioned efficiently. The need to co-operate, the stability of the group of firms, their regular interaction in the precinct, and their similar backgrounds helped breed rich seams of social capital through which trust and cooperation flourished. 58

The buyers were a larger, more diverse group. As indicated in table 2, 31 firms listed buying broker among their occupations, 19 listed themselves as a buyer, and some listed both. Terms like exporter and merchant were also used presumably with a similar role in mind. 67 firms used the more ambiguous term 'wool broker' among their designations. This may have reflected compilation challenges for Skinner's or the fact 
that some buyers occasionally re-sold wool bought at auction. Even on the extreme assumption that none of the firms who designated themselves only as 'wool broker' were buyers, we can still conclude that most firms in the precinct bought wool. Some buyers were small local firms that operated solely from their Melbourne office fulfilling orders on behalf of overseas and a few local manufacturers. Through a variety of sources, including newspapers and histories, we have estimated that at least 36 of the buying firms in the Melbourne precinct were headquartered overseas or were Australian firms with foreign branches. Some Australian firms were established by foreign buyers domiciled in Australia who had left their principal's firm to set up on their own.

Table 1 indicates that about 16 firms were connected to the French textile industry. There was a distinct French-speaking Flanders diaspora among woolbuying firms, who drew heavily upon family and friends to represent them in Australia. Many of these firms began arriving in Australia at the end of the nineteenth century as the local auction system expanded, regular direct shipping services were commenced by Messageries Maritimes (1884) supplying both people and post in return for wool exports, and the French bank Comptoir d'Escompte de Paris (1881) set up in Australia to provide financial services to the wool trade. German, Austrian, and Italian firms were also prominent in Melbourne. The English woollen textile industry was supplied by a range of British and Australian firms along with a few of the larger multinational buying brokers from Europe. 
Most foreign firms sent one or two individual buyers to Australia, principally Sydney and Melbourne, who were carefully trained to understand wool. They often had kinship ties to those who remained on the Continent, facilitating trust and co-ordination across vast distances. Buyers were required to provide regular detailed correspondence and were often called back for a briefing during June and July, when it was summer in Europe and the auctions had finished for the season in Australia. They were expected to remain at their posting for at least a decade. ${ }^{59}$ This demonstrates the care firms took to ensure they had skilled and knowledgeable representatives in foreign wool markets. The combination of the buyer's skills with local networks in Australia, sources of information across global markets, and the omnipresent diaspora provided buyers with the mix of tacit and codified information they needed to bid effectively in the auction room. As one writer has put it, 'the buyer converted his tactile and visual impressions into monetary values, attempting to match his orders against the lots on offer, noting his own price estimates and top limits on the catalogue'.60 Dewez were clear about the great value they attached to their Melbourne woolbuyers, 'The results of the business depend entirely on the skill and ability and personal efforts of these officers ... [including their] knowledge and skill and experience in Australia and overseas'.61

An example of a buying broker with global reach was Masurel Fils, originally founded in Roubaix, France in 1846. One of the earliest foreign buying firms to arrive in Australia in the 1880s, by the 1920s its Melbourne office at 131 William St, adjacent to the MWE, Masurel Fils was part of its global network of branches buying wool in Sydney, Wellington, Durban, Port Elizabeth, East London, Buenos Aires, and Montevideo. The 
firm then shipped wool from these locations to European textile districts including via Dunkirk to Roubaix, via Hull to Bradford, and through Antwerp, Bremen, and Hamburg. ${ }^{62}$

Similar to the woolbrokers, social capital developed in the form of a camaraderie and 'cosmopolitan fraternity' among the foreign buyers who followed the same daily routine, travelled back to Europe together, lived in similar neighbourhoods such as the Melbourne suburb of Kew, and often sent their children to school together. ${ }^{63}$ While British cultural mores were well established in Australia, the Continental buyers fostered cultural and commercial organisations in Australia such as the Société française de Victoria in 1884 and the Alliance Française, whose first branch in Australia was formed in Melbourne in $1890 .{ }^{64}$ French commercial organisations soon followed including the French Chamber of Commerce and Trade Commisioners. Like the brokers, they realised the benefits of co-operation and sharing combined with healthy competition.

\section{The operation of Melbourne's interwar wool trade}

Archival evidence, particularly the minutes of meetings held in the precinct, indicate how the local buzz and international pipelines shaped the progress of the wool trade in the 1920s, including its response to difficult trading conditions, the channels developed for feedback and improvement, the care taken to identify and distinguish wool quality and types, and the specialisations of individual firms. 
The trade faced serious challenges in the post-World War One decade. These included a large wool glut, the transition back to selling by auction, the increased competition from other fibres especially rayon, a cost-price squeeze, the re-integration of servicemen into industry and trade, and the distrust among firms from former combat nations. The close co-operation among members of the wool trade, channelled particularly through industry associations, positioned it well to tackle these challenges. The detailed minutes testify to the cohesive manner in which the trade responded to difficulties. At the end of one meeting of the MWA, chairman Davidson stated 'the brokers were always prepared to meet with the buyers in open conference ... [to] discuss and settle any differences', ${ }^{65}$ a camaraderie that stretched beyond the precinct to the cricket pitch in matches arranged between brokers and buyers.

However, relations were strained by World War One, which profoundly affected those working in the global wool trade. Australians volunteered in large numbers including employees of the major woolbroking firms. European woollen manufacturers and traders were caught in the midst of some of the heaviest fighting in the Flanders region of France and Belgium where many worked and lived. In the aftermath of the 1918 armistice, there was tension within the woolbuying community in Melbourne between British, French and Belgian facing German, Italian and Austrian firms. In August 1919, the committee of the Victorian Woolbuyers Association discussed proposals to limit the activities of buyers from Germany, Austria and other former enemy nations including their exclusion from membership or holding office in the association and permitting them only intermittent access to auctions. ${ }^{66}$ German names disappeared from buyer 
lists after 1918 and it was not until 1922, that Mr C. Schurr, a German buyer and committee member before 1914 , was re-admitted to the association. ${ }^{67}$ By 1930 German buyer M. Eberhardi had become a committee member and the following year so too did S. Akamatsu from Japan, reflecting the growth of that market. 68 The minutes of the industry associations confirm that tensions soon abated in the close community of the wool precinct.

Brokers and buyers cooperated to improve the effectiveness of the wool marketing system. The wartime and postwar centralised marketing schemes brought home to growers the realisation that alternative forms of marketing existed. The expanding army of small primary producers, operating on narrow margins in difficult times, and energised by the support of the Country Party (formed in 1920) reflected on the margin extracted by the middleman broker. ${ }^{69}$ Conscious of this threat to their livelihood and the uncertain trading conditions, the brokers worked with the buyers' and growers' representatives to improve the marketing system. In January 1921, a meeting of the buyers and brokers associations agreed to 28 procedural changes including payment and delivery terms, measurement, catalogues, sale dates, market reports, and sampling. Other meetings discussed the rise of improved road transport, using it to leverage better terms from the railway commissioners. ${ }^{70}$ Together these improvements overhauled and expedited the throughput of the trade. ${ }^{71}$

The wool precinct facilitated learning processes to improve practices such as woolclassing and livestock breeding. In 1926, the MWA discussed the presentation of wool clips, providing advice and noting that they, 'were always writing to get the man in the 
country educated to do what he should do in his own interests'. ${ }^{72}$ In August 1928, addressing the question of uniformity in the description of wool, the Victorian Producers Co-operative representative was asked to explain how his organisation distinguished between greasy and fellmongered wool. ${ }^{73}$

These examples reflect the efforts of traders to acquire the information necessary to distinguish between different types and qualities of wool buyers desired. This included a growing amount of provenance information such as the station on which the wool was grown and the name and credentials of any intermediary who reclassed or repacked the wool before it reached the auction room. In effect, this was a move towards branding. ${ }^{74}$ Buyers wanted to know if the wool came from New Zealand, what the gender was of the sheep, and that good quality of light and ample space would be provided in the inspection store. ${ }^{75}$ Buyers and brokers agreed standard percentages of wool lots that were presented in open bales for inspection. The buyers spoke up against the use of tar in branding or the shearing sheds and the use of binder twine in sewing wool sacks. There was outrage when it was discovered that Younghusband had watered their wool. ${ }^{76}$ The acquired expertise of buyers and brokers, their local presence in the vicinity of the auction, and co-operative behaviour fostered effective sorting of an heterogeneous product.

The significance of local and global information sources is given greater lustre if specialisation existed, as this would point to behaviour consistent with successful information sorting. Several major manufacturing centres receiving Melbourne wool were industrial districts of many small firms with specialist production niches. 
Concentrated around Bradford and the county of Yorkshire, the English industry was highly fragmented in 1927 with around 850 manufacturers of woollen and worsted goods. ${ }^{77}$ Assisted by technologies that enabled smaller firms to operate efficiently, Roubaix also attracted many small specialist manufacturers. ${ }^{78}$

The listings and advertisements in Skinner's confirm specialisation as does our knowledge of which textile manufacturing centres were being supplied and with what types of wool. While some global firms such as Masurel bought widely across the spectrum, smaller firms specialised. In October 1930, a meeting was held specifically of 'buyers interested in the English commission business'. ${ }^{79}$ Combining this with information on shipping movements from contemporary newspapers, it is clear that geographic specialisation occurred. The English market was served by Anglo-Australian firms like Dawson, Laycock and Haughton but also several European traders including Flipo, Prevoust, and Kreglinger \& Fernau. Most French buyers supplied the Flanders manufacturers who were regarded as producing higher quality woollen clothing compared with mass production items from Bradford. ${ }^{80}$ Mazamet in south-east France specialised in woolskins including shipments from Melbourne firms Armand Guilhou and William Houghton. ${ }^{81}$

Specialisation by wool type and use was perhaps more significant since it required specialist knowledge and an ability to distinguish the particular needs of principals back in Europe. Some directory entries indicate types of wool in which a firm specialised. While most firms were in Australia to buy greasy merino and crossbred in general, some dealt in combing or clothing wool, some included slipes and wool skins. If they 
bought clean wool they might specify whether it was home or bale scoured. Others dealt in tops that were either oil or dry combed. Local buying broker Henry Smith advertised that he would ship to any port specifying 'Wools suitable for knitting a speciality. Australian pulled wools ... carbonised wools ... combed tops and noils'. ${ }^{82}$ Thomas Crossland from Bradford specialised as topmakers and noil merchants. Lee and Rogers focussed on the lower end of the market: 'Sundry Wools - Bellies, Blacks and Greys, Crutchings, Damaged, Fallen, Locks and Pieces, Sweepings, Willeyed Locks'.

\section{Conclusion}

This paper analysed the operations of a large service district for a major commodity. It extended the regional clusters literature, which has largely concentrated on production centres or services for intangible products. Our focus, the wool trade, has largely been overlooked in the history of international commodities in the global era. But wool is especially significant for the clusters literature, as it is a heterogeneous commodity that requires expertise and close inspection. Using a large global database of firms and extensive archival evidence of meetings of associations, we have examined the structure of the trade, particularly its local interaction and international connections, and how it operated in Melbourne in the 1920s.

Our analysis reveals how the local concentration of firms in the compact Melbourne wool precinct created a buzz of interaction among selling brokers and buyers around their offices, in the central saleroom, at meetings, and in social organisations in the 
vicinity. This assisted an exchange of information, the sharing of expertise, and the imbuing of tacit knowledge through close engagement with wool selling. Many firms had overseas branches and agencies that provided an international pipeline of information on the wool trade to complement this localisation. Information about global wool markets was exchanged through regular correspondence and cables, and tacit knowledge was gained through regular visits at the end of the selling season. These features shaped the progress of the trade in the difficult conditions of the 1920s. They assisted the recovery of the trade from World War One and the rebuilding of fractured relationships in the sector. Local co-operation and international connections enabled agreed improvements in the efficiency of throughput and offered feedback and branding opportunities to growers, and enabled some firms to specialise by wool type or market.

Our study reveals much about the operations of the key service district in Melbourne's CBD, particularly how its preponderance of small, often foreign, firms with skilled workers distinguishes it from the manufacturing areas on its periphery. Like manufacturing, its operations moved out to the suburbs later in the twentieth century and its grand buildings repurposed for luxury housing and new business, property and financial services. Further, it motivates research on similar districts, particularly in the international commodity trading centres of other settler economies. 
${ }^{1}$ See Harald Bathelt, Anders Malmberg and Peter Maskell, "Clusters and knowledge: local buzz, global pipelines and the process of knowledge creation," Progress in Human Geography 28, no. 1 (2004): 31-56. ${ }^{2}$ Lionel Frost, "Urbanisation," in Simon Ville and Glenn Withers, eds., The Cambridge Economic History of Australia (Melbourne: Cambridge University Press, 2015), 249.

${ }^{3}$ Steven C. Topik and Allen Wells, Global Markets Transformed, 1870-1945 (Cambridge, MA: Harvard University Press, 2014).

${ }^{4}$ Lionel Frost, 'The contribution of the urban sector to Australian economic development before 1914', Australian Economic History Review 38, no. 1 (1998): 42-73; C. B. Schedvin, "Midas and the merino: A perspective on Australian economic historiography," Economic History Review 32, no. 3 (1979): 542 556; J. W. McCarty, "Australian capital cities in the nineteenth century," Australian Economic History Review 10, no. 2 (1970): 107-37.

${ }^{5}$ Alfred Marshall, Principles of Economics (London: Macmillan and Co., 1890).

${ }^{6}$ Emily Buchnea, "Networks and clusters in business history," in John F. Wilson, Steve Toms, Abe De Jong and Emily Buchnea, eds., The Routledge Companion to Business History (London: Routledge, 2017), 25973; Charles Sabel and Jonathan Zeitlin, "Historical alternatives to mass production: politics, markets and technology in nineteenth-century industrialization," Past \& Present 108 (1985): 133-176; Jonathan Zeitlin, "Industrial districts and regional clusters," in Geoffrey Jones and Jonathan Zeitlin, eds., Oxford Handbook of Business History (Oxford: Oxford University Press, 2008); A. S. H. Amin and Nigel Thrift, "NeoMarshallian Nodes in Global Networks," International Journal of Urban and Regional Research 16, no. 4 (1992): 571-587.

7 Giacomo Becattini, Mercato e forze locali. Il distretto industrial (Bologna, 1987).

${ }^{8}$ Sabel and Zeitlin, "Historical alternatives"; Zeitlin, "Industrial districts".

${ }^{9}$ Neil M. Coe, "A hybrid agglomeration? The development of a satellite-Marshallian industrial district in Vancouver's film industry," Urban Studies 38, no. 10 (2001): 1753-55; Gary A. Cook et al., "The role of location in knowledge creation and diffusion: evidence of centripetal and centrifugal forces in the City of London financial services agglomeration," Environment and Planning 39, no. 6 (2007): 1325-45; Nigel Thrift, "On the social and cultural determinants of international financial centres: The case of the City of London in Corbridge," in Nigel Thrift, Stuart Corbridge and Ron L. Martin, ed., Money, Power, and Space (London: Blackwell, 1994); Amin and Thrift, "Neo-Marshallian nodes"; Timothy J. Sturgeon, "What really goes on in Silicon Valley? Spatial clustering and dispersal in modular production networks," Journal of Economic Geography 3, no. 2 (2003): 199-225.

${ }^{10}$ Michael E. Porter, "Clusters and the new economics of competition," Harvard Business Review 76, no. 6 (1998): 77-90; Buchnea, "Networks and clusters".

${ }^{11}$ Kjersten B. Whittington, Jason Owen-Smith and Walter W. Powell, "Networks, propinquity, and innovation in knowledge-intensive industries," Administrative Science Quarterly 54, no. 1 (2009): 90-122. 12 Whittington et al., "Knowledge-intensive industries"; Pierre-Alexandre Balland, Ron Boschma and Koen Frenken, "Proximity and innovation: from statics to dynamics," Regional Studies 49, no. 6 (2015): 907920.

${ }^{13}$ Russell J. Funk, "Making the most of where you are: geography, networks, and innovation in organisations, Academy of Management Journal 57, no. 1 (2014): 193-222; David Audretsch and Maryann Feldman, "R\&D spillovers and the geography of innovation and production," American Economic Review 86, no. 1 (1996): 630-40; Geoffrey G. Bell and Akbar Zaheer, "Geography, networks, and knowledge flow," Organization Science 18, no. 6 (2007): 955-72; Sebastiano Brusco, "The idea of the industrial district: its genesis", in Frank Pyke, Giacomo Becattini and Werner Sengenberger, eds., Industrial Districts and Interfirm Co-operation (Geneva: International Institute for Labour Studies, 1992); Curtis J. Simon and Clark Nardinelli, "The Talk of the Town: Human Capital, Information, and the Growth of English Cities, 1861 to 1961," Explorations in Economic History 33, no. 3 (1996): 384-413.

${ }^{14}$ Sabel and Zeitlin, "Historical alternatives"; Zeitlin, "Industrial districts"; Joel Rast, "Creating a unified business elite: the origins of the Chicago Central Area Committee," Journal of Urban History 37, no. 4 (2011): 583-605.

${ }^{15}$ Amin and Thrift, "Neo-Marshallian nodes"; Zeitlin, "Industrial districts"; Brusco, "Industrial district". 
${ }^{16}$ Ann Markusen, "Sticky places in slippery space: a typology of industrial districts," Economic Geography 72, no. 3 (1996): 293-313; Alex Sayf Cummings, "Brain Magnet': Research Triangle Park and the Origins of the Creative City, 1953-19651," Journal of Urban History 43, no. 3 (2017): 470-92.

${ }^{17}$ Alfred D. Chandler, Scale and Scope: The Dynamics of Industrial Competition (Cambridge, MA: Harvard Business School, 1990), 28-31.

${ }^{18}$ Natasha Glaisyer, "Networking: trade and exchange in the eighteenth-century British empire," The Historical Journal 47, no. 2 (2004): 451-476.

${ }^{19}$ Markusen, "Sticky places".

20 Whittington et al., "Knowledge-intensive industries".

${ }^{21}$ John F. Wilson and Andrew Popp, Industrial clusters and regional business networks in England, 17501970 (London: Ashgate, 2003) contains a broad range of case studies. See also S. A. Caunce, "Complexity, community structure and competitive advantage within the Yorkshire woollen industry, c.1700-1850," Business History 39, no. 4 (1997): 26-43; Gillian Cookson, "Family firms and business networks: textile engineering in Yorkshire, 1780-1830," Business History 39, no. 1 (1997): 1-20; Francesca Carnevali, "Golden opportunities: jewelry making in Birmingham between mass production and specialty," Enterprise and Society 4, no. 2 (2003): 272-298; Roger Lloyd-Jones and Myrddin J. Lewis, "Personal capitalism and British industrial decline: the personally managed firm and business strategy in Sheffield, 1880-1920," The Business History Review 68, no. 3 (1994): 364-411; Andrew Popp, "Governance at points of corporate transition: networks and the formation of the United Alkali Company, 1890-1895,"

Enterprise \& Society 7, no. 2 (2006): 315-352; Peter Maw, Terry Wyke, and Alan Kidd, "Canals, Rivers, and the Industrial City: Manchester's Industrial Waterfront, 1790-1850," Economic History Review 65, no. 4 (2012): 1495-523.

22 Philip Scranton, Proprietary capitalism: The textile manufacture at Philadelphia, 1800-1885 (Cambridge: Cambridge University Press, 1983); Joan C. Cirer-Costa, "Majorca's tourism cluster: the creation of an industrial district, 1919-36," Business History 56, no. 8 (2014): 1243-1261; Julie McIntyre, Rebecca Mitchell, Brendan Boyle and Shaun Ryan, "We used to get and give a lot of help: networking, co-operation and knowledge flow in the Hunter Valley wine cluster," Australian Economic History Review 53, no. 3 (2013): 247-267; Aitziber Elola, Jesus M. Valdaliso, Santiago M. López and Mari J. Aranguren, "Cluster life cycles, path dependency and regional economic development: insights from a meta-study on Basque clusters," European Planning Studies 20, no. 2 (2012): 257-279; Mary B. Rose, Firms, networks and business values: the British and American cotton industries since 1750 (Cambridge: Cambridge University Press, 2000); Tomoko Hashino and Keijiro Otsuka, Industrial Districts in history and the developing world (Singapore: Springer, 2016).

${ }^{23}$ N. G. Butlin, Investment in Australian economic development, 1861 - 1900 (London, Cambridge University Press, 1964), 182; Tony Dingle and Seamus O'Hanlon, "From manufacturing zone to lifestyle precinct: economic restructuring and social change in inner Melbourne, 1971-2001," Australian Economic History Review 49, no. 1 (2009): 52-69; Peter Yule ed., Carlton: A History (Melbourne: Melbourne University Press, 2004); T. Birch, 'Fitzroy' in Andrew Brown-May, and Shurlee Swain, eds. The Encyclopedia of Melbourne (Cambridge: Cambridge University Press, 2005); David Merrett, "Australian Capital Cities in the Twentieth Century," in J. W. McCarty and C. B. Schedvin, eds., Australian Capital Cities: Historical Essays (Sydney: Sydney University Press, 1978).

${ }^{24}$ J. W. McCarty, "Australian Capital Cities in the Nineteenth Century," Australian Economic History Review 10, no. 2 (1970): 107-37; Lionel Frost, The New Urban Frontier. Urbanisation and City Building in Australia and the American West (Kensington: UNSW Press, 1991); Lionel Frost, "'Metallic Nerves': San Francisco and Its Hinterland During and after the Gold Rush," Australian Economic History Review 50, no. 2 (2010): $129-47$.

${ }^{25}$ See also William Cronon, Nature's Metropolis: Chicago and the Great West (New York: WW Norton \& Company, 1991) for an analysis of resource stocks and flows between Chicago and its hinterland.

${ }^{26}$ John Haggerty and Sheryllynne Haggerty, "The life cycle of a metropolitan business network: Liverpool 1750-1810," Explorations in Economic History 48, no. 2 (2011): 189-206; Cirer-Costa, "Majorca's tourism cluster"; Amin and Thrift, "Neo-Marshallian nodes". 
${ }^{27}$ Peter Richardson, "The origins and development of the Collins House Group, 1915-51," Australian Economic History Review 27, no. 1 (1987): 3-29; Peter Yule, William Lawrence Baillieu: Founder of Australia's Greatest Business Empire (Melbourne: Hardie Grant Books, 2012).

${ }^{28}$ Amin and Thrift, "Neo-Marshallian nodes"; Haggerty and Haggerty, "Metropolitan business network".

${ }^{29}$ Cook et al., "Knowledge creation and diffusion"; Amin and Thrift, "Neo-Marshallian nodes"; Thrift,

"International financial centres"; Haggerty and Haggerty, "Metropolitan business network".

${ }^{30}$ David Greasley, "Industrialising Australia's natural capital," in Simon Ville and Glenn Withers, eds., The

Cambridge Economic History of Australia (Melbourne: Cambridge University Press, 2015), 150-77.

31 Paul Cashin and C. John McDermott, “'Riding on the sheep's back': examining Australia's dependence on wool exports," Economic Record 78, no. 242 (2002): table 1, 251.

${ }^{32}$ Stephen Brearley, "The international wool market, 1840-1913" (Ph.D. thesis, University of Leicester, 2004), 48.

${ }^{33}$ C. B. Schedvin, "Staples and regions in Pax Brittanica," Economic History Review 43, no. 4 (1990): 533559.

${ }^{34}$ Cashin and McDermott, "'Riding on the Sheep's Back"', table 1, 251; Christian Gillitzer and Jonathan Kearns, "Long-term patterns in Australia's terms of trade" (Research Discussion Paper, Reserve Bank of Australia, 2005), 12.

${ }^{35}$ Alan Barnard, The Australian Wool Market (Melbourne: Melbourne University Press, 1958); Syd J.

Butlin, Australia and New Zealand Bank: The Bank of Australasia and the Union Bank of Australia Limited, 1828-1951 (London: Longmans, 1961).

${ }^{36}$ Nancy Windett, Australia as producer and trader, 1920-1932 (London, 1933), 48-63.

${ }^{37}$ W. R. Lang, "The Australian wool clip," in Alan Barnard, eds., The Simple Fleece (Melbourne: Melbourne University Press, 1962), 15-26.

38 ML MSS 2094, box Y768, correspondence dated c.11 June 1934.

${ }^{39}$ See Anne K. Knowles and Amy Hillier eds., Placing history: How maps, spatial data, and GIS are changing historical scholarship (Redlands: ESRI, 2008) for an overview.

${ }^{40}$ Ian N. Gregory and Alistair Geddes, Toward spatial humanities: Historical GIS and spatial history

(Bloomington: Indiana University Press, 2014).

${ }^{41}$ Haggerty and Haggerty, "Metropolitan business network" use digital methods in the form of social network analysis for their study of Liverpool's trade services district.

${ }^{42}$ Available online from the State Library of Victoria, see http://handle.slv.vic.gov.au/10381/287999.

${ }^{43}$ State Library of N.S.W., Mitchell Library research collections (hereafter ML) MSS 2094, box Y768

particularly the shipping records of the firm.

${ }^{44}$ Graeme Davison, The Rise and Fall of Marvellous Melbourne (Melbourne: Melbourne University Press, 1978); Clifford M. Zierer, "Melbourne as a Functional Center," Annals of the Association of American Geographers, no. 4 (1941): 251-88.

${ }^{45}$ Zeirer, "Melbourne as a function center".

${ }^{46}$ See Davison, Marvellous Melbourne for a description of the segregation of Melbourne's CBD into distinct commercial districts in the late-nineteenth century.

${ }^{47}$ Frederick F. Knight, History of the Australian Club, volume 2, 1932-1965 (Melbourne, 1971).

48 MWE Register of Directors, Members, Documents. UMA 106/121, box 1, 2/1.

${ }^{49}$ Previously sales and meetings had been held in the Rialto and Olderfleet buildings, built in 1891 and located at 497-503 and 475-7 Collins St.

${ }^{50}$ University of Melbourne Archives (hereafter UMA), accession 79/178, MWA General Committee minutes, 25 June 1918.

${ }^{51}$ Dewez company's wool buyers wrote business correspondence from the Australia Club and voted in elections for new club members. See ML MSS 2094 Dewez Collection correspondence from 'Tue' (Toussaint Jnr) to Gus Dewez dated 2 February 1934 and 7 February 1934. Election ballot dated 26 June 1934. ML MSS 2094, box Y768.

${ }^{52}$ Ann Moyal, Clear across Australia: A History of Telecommunications (Melbourne: Nelson, 1984).

53 ML MSS 2094, box Y779. Code books and note books. By the 1920s, inter-state telephone lines supplemented the telegraphic communications of firms. 
${ }^{54}$ Jean-Pierre Daviet, "Le complexe industriel de Roubaix-Tourcoing et le marché de la laine (18401950)," Revue du Nord 69, no. 275 (1987): 777-813.

${ }^{55}$ E. Dean Vaughan, "The benefits and costs of the tariff on wool," (Ph.D. thesis, Montana State College, 1947).

${ }^{56}$ Bureau of Agricultural Economics, The structure of the Japanese wool textile industry (Canberra, 1969),

34-6. There is evidence of Chinese interest in direct wool purchases by the 1930s. See ML MSS 2094, box

Y768, Dewez company correspondence dated 15 June 1934.

57 W. Purcell, "Japanese trading companies in Australia, 1890-1941," Australian Economic History Review

21, no. 2 (1981): 124-8.

${ }^{58}$ David Merrett and Simon Ville, "Institution building and variation in the formation of the Australian

wool market," Australian Economic History Review 53, no. 2 (2013): 146-66; David Merrett, Stephen

Morgan and Simon Ville, 'Industry associations as facilitators of social capital: the establishment and early operations of the Melbourne Wool Brokers Association', Business History 50, 6 (2008): 781-94.

59 John Rosemberg, "Studies in the French presence in Australia," (Masters thesis, Monash University, 1985), 5.

${ }^{60}$ Rosemberg, "French presence in Australia", chapter 5.

${ }^{61}$ ML MSS 2904, boy Y768. Correspondence dated 1 June 1934.

${ }^{62}$ Daily commercial news and shipping list, 14 Nov. 1923.

${ }^{63}$ Jacqueline Dwyer, Flanders In Australia: a personal history of wool and war (East Roseville, $1^{\text {st }}$ edn, 1998), 18, 32-7.

${ }^{64}$ Dwyer, Flanders in Australia, 1st ed, chs 3, 4, 19, 20; Robert Aldrich, "Commercial relations between France and Australia: an historical overview," in Anne-Marie Nisbet and Maurice Blackman, eds., The French-Australian cultural connection (Sydney: UNSW Press, 1984), 73-5; Anny P. L. Stuer, The French in Australia (Canberra, 1982), 129.

${ }^{65}$ UMA, 79/178, MWA trade committee minutes, 4 July 1930.

${ }^{66}$ UMA, VSAWA minutes 1906-13, box 44, 22/1/3. Agenda for special meeting 22 August 1919.

67 UMA, VSAWA minutes $1913-25$, box $26,6 / 1 / 1$.

68 UMA, VSAWA minutes 1926-34, box 37, 27/1/1.

${ }^{69}$ Bruce D. Graham, The Formation of the Australian Country Parties (Canberra: ANU Press, 1966).

${ }^{70}$ UMA 79/178 MWA trade committee minutes, 12 September 1922.

71 UMA 79/178 MWA general committee minutes, 21 January 1921.

72 UMA 79/178, MWA trade committee minutes, 12 March 1926.

73 UMA 79/178, MWA trade committee minutes, 29 August 1922

${ }^{74}$ For example, UMA 106/121, VSAWA minutes 1926-34, box 37, 27/1/1. 1 October 1927.

75 UMA 106/121, VSAWA minutes 1926-34, box 37, 27/1/1. 14 December 1928, 22 February 1929, 13 June 1929.

${ }^{76}$ UMA 106/121, VSAWA minutes, box 37, 27/1/1. Meeting on 15 October 1928, 13 June 1929, 1 April 1933.

${ }_{77}$ Skinner's, The world's wool.

${ }^{78}$ Sabel and Zeitlin, "Historical alternatives," 145-6.

79 UMA, VSAWA minutes 1926-34, box 37, 27/1/1. 24 October 1930.

80 Daviet, "Roubaix-Tourcoing," 786.

${ }^{81}$ Daily commercial news and shipping list, 20 Jan. 1926, 5.

${ }^{82}$ Skinner, The world's wool, 185 